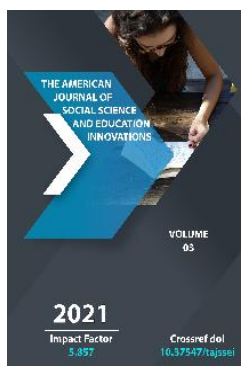

\title{
Irrigation System Of Turkestan In The Second Half Of 19th Century And Early 20th Century
}

\author{
Umidjon Abdimavlyanovich Usarov \\ PhD Researcher, Department Of "History Of Uzbekistan" National University Of Uzbekistan \\ Tashkent, Uzbekistan
}

\begin{abstract}
Journal Website: http://theamericanjour nals.com/index.php/taj ssei

Copyright: Original content from this work may be used under the terms of the creative commons attributes 4.0 licence.
\end{abstract}

\section{ABSTRACT}

This article describes the state of irrigated agriculture in Turkestan, water sources, classification of major rivers and their tributaries, geographical location, irrigation system, sources of water supply, types of traditional irrigation methods used by the local population in the second half of the 19th and beginning of the 2oth century. Moreover, an attempt is made to reveal the participation of local people in the construction, repair, cleaning of irrigation facilities, the implementation of centuriesold rules of irrigation, the rights of local people to use water through a number of sources, statistical collections, scientific literature and research works in the article.

\section{KEYWORDS}

The country of Turkestan region, Russian Empire, region, Fergana, Syrdarya, Samarkand, water sources, river, Chirchik, Zarafshan, canal, irrigation system, agriculture, water facilities, mirab, aksakal, desiatina.

\section{INTRODUCTION}

In the second half of the 19th century, the Russian Empire began to pursue a policy of achieving its geopolitical goals in Central Asia, taking into account all its interests in the country. According to the instructions of the government of the Russian Empire, the changes in land and water relations in Turkestan and in general, the agrarian policy were aimed primarily at turning the country into the base of the metropolis for cotton, cocoons and other agricultural products.

In particular, according to the Minister of State Property and Agriculture AV Krivoshein, the main goals and main directions of the Russian Empire's agrarian policy which includes land and water relations in Turkestan: 
"There are three views on this central issue. The first is cotton, the second is irrigation, and finally, the third, though insignificant, is, in fact, the most important thing - the resettlement of the Russians" [2, -P. 111]. Thus, the emperor's minister summed up the main directions of the center's colonial policy in the country of Turkestan in three words: "cotton", "irrigation", " resettlement of Russian "[7, -P. 215]. The emphasis of the imperial government on the irrigation system and water resources in Turkestan at that time based on its own interests shows the topicality of the issue.

\section{RELATED WORK}

The study of the irrigation system and water sources of the country of Turkestan as well as the traditions and methods of water use of the local population in the second half of the 19th century - early 20th centuries, are reflected in a number of sources and literature. Particularly, information on this topic can be found in the works of the following authors. Among them, A.I.Shakhnazarov (1908), N.N.Aleksandrov (1916), A.P.Savitsky (1963), A.M.Yuldashev (1969), A.R. Muhammadjonov (1972), Z.D. Kastelskaya (1980), Sarybaev K.S. (1995), H.E. Yunusova (2018), U.A.Usarov (2018, 2019). and works and research papers of other of authors can be included. Information on the irrigation system of the late XIX - early XX centuries can also be found in the annual collections of "Statistical materials of the country of Turkestan " in different years.

\section{METHODOLOGY}

In writing this article, such methods as the analysis of historical data, systematic, historical accuracy, comparative analysis were used. The article reveals the water resources, the irrigation system, the methods used in it and the peculiarities of the irrigated agriculture of the local population in the country of Turkestan in the second half of the XIX - early XX centuries.

\section{RESULTS AND DISCUSSION}

In the second half of the 19th century - early 2oth century, the situation with irrigated agriculture in Turkestan, whose main income was agricultural products, was not the same in all regions. Therefore, water was used in different ways in different parts of the country depending on water sources and irrigation system. During this period, the local population of the country of Turkestan had a great deal of experience in irrigating. Regarding this, N.N. Aleksandrov, who studied the irrigation of the local population of Turkestan, in particular, the Syrdarya region, described that "the locals are skilled in such work" [1, -P. 22]. The author also goes on to comment on the specific methods used to determine the level of water and slope in the low and high parts of the land used by the local population for cultivation: "In many cases, the locals were able to correctly determine the slope of the field and the direction of the water by eye or by some simple method, such as a horizontal bowl filled with water." [2, -P. 22-23]. The Russians, who had little experience in the irrigation system, solved the problem with experienced local representatives.

In the second half of the 19th century and the beginning of the 2oth century, the Fergana, Syrdarya and Samarkand regions of Turkestan were the regions with the highest agricultural production, in which agriculture was carried out mainly on the basis of artificial irrigation[9, -P. 513-515]. In particular, according to A.I. 
Shakhnazarov, who studied land-water relations in the country's agriculture, a total of $1,874,900$ desyatinas of land in these three regions of Turkestan consisted of artificially irrigated land. In terms of regions, irrigated lands in the country accounted for 947,700 desyatinas of land in Fergana region was 50\%, 401,200 desyatinas in Samarkand region showed 21.4\%, 526,000 desyatinas in Syrdarya rated $28.1 \%$ of all irrigated land[10, -P. 87]. While these areas were rich in water resources, the locals had also the judicious use of water in agriculture, these regions grew the country's main agricultural products[11, -P. 4347].

Irrigated lands in almost all areas of Turkestan, rich in water resources, got their water from streams formed by rivers, rivulets, and springs that flew from mountain slopes. Many villagers irrigated their arable lands through streams that flew down from the mountains. For example, the irrigated lands of the Governor-General of Turkestan in the Fergana region were located in the Sir Darya basin, which is 440,000 desiatins of land, in particular, $55.4 \%$ of the total area. However, not much water from the Sir Darya was used for irrigation while water for irrigation was obtained mainly from the Naryn and Karadarya rivers. In addition, in Namangan uezd - Hasansay, Olmossay, Mulla-amir, in Margilan - Isfayron, in Kokand - Sokh, Isfara rivers and streams were widely used for irrigation[10, -P. 87]. Local peasants made efficient use of quick and inexpensive irrigation facilities using soil, stone, wood, reeds, twigs and other materials. Peasants had been building, repairing and cleaning irrigation networks several times a year by khashar (obligatory unpaid labor).

In the Syrdarya region of the country there were large irrigated lands, which were mainly around the Sir Darya and its major tributaries, the rivers Chirchik, Angren, Aris, Bodom, Borijar, Chayon and Talas. The main water source of the region was Sir Darya. The river starts in the Fergana Valley and flows into the Syrdarya region. Its irrigation moisture was rich, and large tributaries such as Chirchik, Ahangaron, Keles, Aris supplied water to a large part of the region. In addition, the Sir Darya River flew into the Aral Sea without being used, besides the water used to irrigate about 3,000 desyatinas of land in Perovsky and Kazalinsk uezds[1, -P.12].

The richness of the Sir Darya water source can also be seen in the water supply of its large tributaries. For example, according to the sources of that period, the irrigated lands along the Chirchik River were 281,828 desiatins, which was 53.6 percent of the total irrigated area of the whole region[10, -P. 87]. The Chirchik River was the main river supplying water to Tashkent uezd and surrounding areas, 2/3 of which was used for irrigation[1, -P. 12]. Also, according to the Turkestan Regional Statistics Committee in 1876 , all water sources irrigating Tashkent, the center of the Syrdarya region and its environs were taken from the Chirchik River, which flows through the southwestern foothills of the Chatkal Mountain Range and data occurs that it flew eight miles south of the city and flew into the Sir Darya as it approached the city of Chinaz[3, -P. 261].

Almost all the waters of the Akhangaron and Keles rivers, other smaller tributaries of the Sir Darya, were used for irrigation in the Tashkent uezd. At the same time, the Aris River supplied water to the Chernyaev (Shymkent) uezd, where only $1 / 4$ of the runoff was used for irrigation. Avliyota uezd was supplied with water by rivers such as Talas, Asa and Ters. The most important of these was the Talas 
River, which was used to irrigate $2 / 3$ of the district's irrigated land. Irrigated lands in the eastern part of Avliyota district were used to supply water from the tributaries of the Chu River. It should be noted that the Chernyaev (Shimkent) and Avliyota uezds of the Syrdarya region, in addition to the above-mentioned out-of-river waters, were also irrigated by many springs in the foothills $[1,-P .12-13]$. Irrigated lands in the Amudarya district of the region were mainly irrigated by canals and ditches that received water from many large and small tributaries of the Amu Darya[6, -P. 82].

In general, many large ditches (local canals) were widely used to irrigate the existing crop fields in the Syrdarya region. These canals played a very important role in irrigation. For instance, According to N.N. Alexandrov who studied regional irrigation, there were a total of 3006 large and small canals in the region, which were 17,151 versts in length. About 600,000 desyatinas of land were irrigated with these canals, of which 70,000 desiatinas were much water-intensive rice fields $[1,-P .13$; 8, -P. 35-36].

In Samarkand region, 269,000 desiatins of large-scale irrigated land were located along the Zarafshan River, which was 67 percent of all irrigated land in the region. The Zarafshan River itself supplied irrigated lands in Samarkand and Bukhara[10, -P. 87]. According to A.R. Muhammadjanov, a scientist who studied the history of irrigation in the Zarafshan oasis, in the second half of the 19th century the main source of water in the Samarkand region was the Zarafshan River, from which water flew to 56 canals, 42 of which supplied water to Panjakent and Samarkand district, and 14 which supplied water to Kattakurgan district. The total area of irrigated land from this canal in the region was 9893.79 kush (1 kush equals about 13.02 desiatinas) or 128818.75 desiatinas (1 desiatina is equal to 1.09 hectares). The abovementioned canals irrigated 7410.25 kush or 96487.5 desiatinas of land in Samarkand district and 2483.53 kush or 32331.25 desiatinas of land in Kattakurgan district. According to the report in 1888 by the military governor of the Samarkand region to the Russian Ministry of Military, a total of 142 main canals were used to draw water from the Zarafshan River, 99 of which supplied water to the Samarkand region and 43 to the Bukhara emirate. In the Zarafshan oasis, out of 1924 secondary canals, 985 were located in Samarkand and 939 in Bukhara[4, -P. 202]. It is obvious that after the Russian Empire had established its power in the Samarkand region, it took full control of the water distribution of the Zarafshan River.

In all regions of Turkestan below five methods were used for irrigation. They are: 1) Open irrigation method - this method is the simplest and most natural, which was used to irrigate flat fields that were not much larger. Water flowing from a permanent ditch was released into the field along a large stream from one or more places. 2) The method of "sedimentation" - is another type of irrigation, for which the floor is removed from the plowed land, and the soil inside it is plowed and filled with water evenly. The locals widely used the method in planting rice and alfalfa. 3) Through the wavy ditches or, in the vernacular language, the "juyak" method - the water opened in this way fills the ditches almost to the top and only moistens the roots of the plants. This method was used by the locals to plant cotton, carrots, melons and other handgrown crops. In addition, water accumulates in the furrow and the nutrients are not washed out of the soil. Irrigation with wavy ditches was a low-cost method and was 
effective. 4) The method of irrigating parallel furrows with a small stream was a less common method. This method was applied on a flat area, without wavy ditches. In it the plants were placed in a row. In this case, the water flew from both sides of them. As the water flew into each ditch as a small stream, the water reached the end of the ditches. 5) The method of "flooding" - in appearance it is similar to the method of artificial and natural irrigation. But in this way the river and lake front areas were flooded with river water. For example, it was used in front of large rivers such as the Amu Darya and the Sir Darya. When the rivers ran low, the land was recultivated and crops were planted. More melons, wheat, barley and similar crops were planted on these lands[1, -P. 23-36].

In the Turkestan country during this period, the local population followed its own rules for water use for centuries. In particular, they consisted of:

1. Water was a blessing given by Allah and it was not considered anyone's personal property. Only those who invested in a water collection facility could own the water they collected.

2. It was not possible to sell or buy water.

3. All water users were obliged to participate in the construction and cleaning of irrigation facilities.

4. The use of canals on private lands was entrusted to the owners of these lands.

5. Water could not be sold without land.

6. It was obligatory to distribute water evenly in times of water shortage.

7. The order of water use was determined by lot.

8. At the time of the water shortage, first the landowner below, then the landowner above could irrigate their land.
9. It was a crime to steal water and irrigate one's land in any case, and the landowner was punished accordingly.

10. Construction of various barriers to ditches, mills or drainage facilities was not carried out without the permission of the owner of the flooded lands.

11. Water users had to plant various seedlings along the banks of the ditches.

12. "Mirab" was chosen among the people who have experience and reputation among the villagers in the proper use of water and its direction.

13. It was not possible to complain about the mirabs. Only after the harvest, certain part of the harvest was given to mirabs, depending on the service rendered by them.

14. If several villages used the same ditch for irrigation, a mirab leader was appointed among those who lived in accordance with Sharia law and had a reputation in the village in order to control the proper distribution of water by the mirabs. They were also paid in kind.

15. In case of erosion of irrigation facilities and water leakage, a "dam man" was appointed by the head of the mirab leader. Their task was to oversee the construction and renovation of many structures that were rapidly destroyed by irrigation canals and ditches, rivers and streams. Tasks such as the construction of drainage structures including "sepoya", "chorpoya”, "kara boira”, "korabura” and their installation in the canal, could not be done without their participation.

16. The water was distributed equally among the members of the congregation according to the number of "qulaqs" (little open part of ditches used to separate the water). The amount of water coming out of one qulaq was equal to the 
amount of water needed to move a single stone of the local mill.

17. All peasants who used ditch water for irrigation were required to participate in the cleaning and repair of ditches. If one village used more water than the other, the people who used more water would have to leave the labor force more. They were also appointed by the mirab or mirabboshi.

18. The villagers between the two ditches had to use a ditch above the village to irrigate the land, so that after irrigation the water from above irrigated the land flew into the ditch below, thus filling the lower ditch and preventing water from accumulating in the neighboring lands.

19. Every Muslim was required by Sharia law to participate in the construction of irrigation facilities.

20. In case of disagreement over the distribution of water, the two parties appealed to the village aksakal (leader of villagers), who reconciled the two parties in accordance with Sharia $\operatorname{law}[10,-P .91$ 92; 5, -P. 3-209].

These water use rules mentioned above had been followed as a strict rule among the local population. Their full compliance was supervised and controlled by local aksakals and mirab officials.

There were very few unused water reserves in the country. Therefore, it was difficult to develop the lands that were drying up with this amount of water. It was widely used in cattle breeding and karakul farming on such lands.

\section{CONCLUSION}

In general, the irrigated farming culture of the country of Turkestan in the second half of the 19th century was based on the rich experience of the past centuries, which made efficient use of water resources in agriculture. During this period, the population of Turkestan widely used several methods of irrigation due to the diversity of irrigated lands, climate, geographical location, soil composition, productivity, proximity to water sources and other characteristics. From the earliest years of the Russian Empire's establishment of its colonial policy in Turkestan, it was unable to fully dominate the country's irrigation system, as its main goal was to acquire agricultural products, particularly cotton, cocoons, and other products. In this case, the representatives of the Russian government had to cede to them, as they could not do anything in the country without the help of the local population. The people of the country also attached great importance to following a number of regulations in the use of water resources. This allowed the people of the country to use the available water resources on an equal basis.

However, by the end of the 19th and the beginning of the 2oth centuries, as a result of the policy of the government of the Russian Empire on the development of cotton growing in Turkestan, the region had a significant impact on water resources and irrigation systems. The impact of factors such as excessive cotton planting, misconduct in the acquisition of new lands, inefficient use of water resources, delays in the maintenance of irrigation networks and facilities, and deterioration of the social status of local peasants led to the tottering of irrigation in the country. Representatives of the government of the Russian Empire, on the other hand, focused their efforts on improving 
irrigation in the country only if it was in their interests.

\section{REFERENCES}

1. Александров Н.Н. Земледелие в СырДарьинской области. -Т.: Часть 1-2, 1916. -C. 12,13, 22-23-36. (Alexandrov N.N. Agriculture in the Syr-Darya region. - T .: Part 1-2, 1916. -P. 12.13, 2223-36.)

2. Кривошеин А. В. Записка главноуправляюшего земледелием и землеустройством о поездке в Туркестан. СПб. 1912. -С. 111. (Krivoshein A. V. Note of the chief manager of agriculture and land management about a trip to Turkestan. SPb. 1912. -P. 111.)

3. Материалы для статистикие Туркестанскаго края. Ежегодник. Выпуск IV. -С-Пб.: 1876. -С. 261. (Materials for statistics of the country of Turkestan. Yearbook. Edition IV. -SPb.: 1876. -P. 261)

4. Мухаммаджонов А.P. Қуйи Зарафшон водийсининг суғорилиш тарихи (Қадимги даврдан то XX аср бошларигача). -Т.: Фан, 1972. -Б. 202. (Muhammadjonov A.R. History of irrigation of the Lower Zarafshan valley (From ancient times to the beginning of the 2oth century). -T.: Fan, 1972. -P. 202.)

5. Савицкий А.П. Поземленый вопрос в Туркестане (в проектах и законе 1867-1886 гг.) -Ташкент: 1963. - С. 14,15,37. (Savitsky A.P. The land issue in Turkestan (in the projects and the law of 1867-1886) - Tashkent: 1963. - P. 14,15,37. (Savitsky A.P. The land issue in Turkestan (in the projects and the law of 1867-1886) - Tashkent: 1963. - P. 14,15,37.)
6. Сарыбаев К.С. История орошения Каракалпакстана (с конца XIX века до наших дней). -Нукус. Каракалпакстан, 1995. -С. 82. (Sarybaev K.S. Irrigation history of Karakalpakstan (from the end of the 19th century to the present day). Nukus. Karakalpakstan, 1995. -P. 82.)

7. Ўзбекистоннинг энг янги тарихи: Туркистон чор Россияси мустамлакачилиги даврида. Биринчи китоб. -Тошкент: Шарқ, 2000. -Б. 215. (Recent history of Uzbekistan: Turkestan in the period of Tsarist Russia. The first book. -Tashkent: Sharq, 2000. -P. 215.)

8. Усаров У.А. Освещение земельноводных отношений в Туркестанском крае в трудах русских исследователей // "Advances in Science and Technology" XXIV Международная научнопрактическая конференция. Сборник статей. часть II. -Москва, 2019. -С. 36. (Usarov U.A. Coverage of land and water relations in the Turkestan region in the works of Russian researchers // "Advances in Science and Technology" XXIV International Scientific and Practical Conference. Digest of articles. part II. -Moscow, 2019. -P. 36.

9. Usarov, U. A. (2019). Some considerations on the pecularities of Russian empire's politics in Turkestan. ISJ Theoretical \& Applied Science, 12 (80), P. 513-515.

10. Шахназаров А.И. Сельское хозяйство в Туркестанском крае. Санкт-Петербург: 1908, -С. 87, 91-92. (Shakhnazarov A.l. Agriculture in the country of Turkestan. -Saint Petersburg: 1908, -P. 87, 91-92.

11. Юнусова Х.Э., Усаров У.А. Некоторые суждения об истории 
земледельческой культуры в Средней Азии. Наука, техника и образование. -Москва. 2018. №9 (50). -C. 43-47. (Yunusova Kh.E., Usarov U.A. Some judgments on the history of agricultural culture in Middle Asia. Science, technology and education. -Moscow. 2018. No. 9 (50). -

P. 43-47.) 